\title{
Research on the Mechanism of Main Roof Advanced Breaking and Supporting Technology When Long-wall Face Passing Through Abandoned Roadways
}

\section{Pan Weidong}

China University of Mining and Technology - Beijing Campus

\section{Deng Cang}

China University of Mining and Technology - Beijing Campus https://orcid.org/0000-0002-3383-6256

\section{Li Boyang}

China University of Mining and Technology - Beijing Campus

Zhang Kunming ( $\nabla$ dc_okk@163.com )

China University of Mining and Technology - Beijing Campus https://orcid.org/0000-0002-0140-4096 Gao Shan

China University of Mining and Technology - Beijing Campus

\section{Research}

Keywords: passing through abandoned roadways, key block stability, theoretical analysis, numerical simulation, roof supporting technology

Posted Date: August 10th, 2021

DOl: https://doi.org/10.21203/rs.3.rs-775784/v1

License: (c) (i) This work is licensed under a Creative Commons Attribution 4.0 International License.

Read Full License 


\title{
Research on the mechanism of main roof advanced breaking and supporting technology when long-wall face passing through abandoned roadways
}

\author{
Pan Weidong, Deng Cang, Li Boyang, Zhang Kunming*, Gao
}

\author{
Shan \\ (School of Energy and Mining Engineering, China University of Mining and \\ Technology, Beijing, 100083, China)
}

\begin{abstract}
Unlike general long-wall mining, the roof activity is more intense when longwall face passes through the abandoned roadway. Technically, the coal pillar between the abandoned roadway and the long-wall face will suddenly fail with a certain critical value of its width, leading to the roof breaks in advance and other production-restricted problems because of the support loss, which will be a great threat to underground mining activities. In order to guarantee a safe mining condition, therefore, it is greatly necessary to uncover how the roof breaks in advance and how to cope with it. From the stability maintaining of the key block perspective, this paper took for research that the 12404-1 long-wall face of Wulanmulun coal mine, China. The critical value of the coal pillar's width was determined to be about $5 \mathrm{~m}$ by theoretical analysis, likely, the appropriate support force of the abandoned roadway's roof is about $4020 \mathrm{KN}$ per meter. Meanwhile, a numerical simulation method was adopted to study the ground pressure when the longwall face passing through the abandoned roadway. Correspondingly, a compound supporting technology involving the roof presplit technique, anchor cable supporting and pumping pillar supporting were proposed for the roof of the abandoned roadway, and it practically worked well.
\end{abstract}

Keywords: passing through abandoned roadways; key block stability; theoretical analysis; numerical simulation; roof supporting technology

\section{Introduction}

In China, underground mining plays an important role in the exploitation of coal resources, more than 3 billion tons of coal is extracted from underground mines every year, and thousands of kilometers roadway is tunneled to extract such amount of coal. These roadways play a functional role in the coal mine production: a few are used for transportation while others are used for ventilation (FEM-DEM numerical analysis of support design when long-wall face strides across and passes a cross-cut) [1]. Some of these roadways would be abandoned when reached their servicing age. Therefore, it is inevitable to encounter a situation in which these roadways lay in the range of the long-wall face, and the long-wall face must pass through these abandoned roadways for a positive production [2]. 
However, there are differences in strata behaviors of whether the long-wall face passes through the roadway. In this case, a series of problems will arise which would terribly restrict the production efficiency of the long-wall face. Numerous engineering practices have verified that, the coal pillar located between the long-wall face and the abandoned roadway would suddenly fail when the width of the coal pillar reaches a critical value. Meanwhile, the main roof may break in advance due to the support loss from the coal pillar, resulting in coal rib spalling, support crushing, roof falling, etc. Undoubtedly, these issues could be a great threat to the safety of mining activities. In this area, where stronger ground pressure would occur, many studies have been initiated in the past years [34], Li et al [5] and Gu et al [6] studied the relationship between the supports and surrounding rock when the long-wall face passing through the abandoned roadway. Xie et al [7] studied the ground pressure mechanism when the long-wall face passing through the abandoned roadway. Bai et al [89] and Zhao et al [10] established a mechanical model of the roof advanced breaking when the longwall face passing through the abandoned roadway. Gong et al [11-14] analyzed the influencing factors of the roof's advanced breaking when the long-wall face passing through the abandoned roadway. Respectively, AAM (adjusting the angle method) to pass through the abandoned roadway, FRT (filling the roadway technique) to control the roof of abandoned roadway, were proposed in these studies above.

Despite those previous researches and the evidence of the existence of advanced breaking, the advanced breaking mechanism of the main roof is still unclear, which hinders the management of support resistance. Moreover, the key block stability of the broken roof strata and its influence on the long-wall face surrounding rock need further analysis and research. In addition, better control of the surrounding rock also is key for safe mining [15-17]. Therefore, it is very important to propose a corresponding supporting technology to the roof of the abandoned roadway.

Considering these issues remained, in this paper, the mechanism of the roof advanced breaking is revealed and a theoretical model is established to analyze the stability of the key block when the long-wall face passes through the abandoned roadway; the ground pressure around the long-wall face and abandoned roadway is further studied by DEM numerical simulation; a new abandoned roadway supporting technology is proposed to control the stability of the long-wall face; and to verify this new support design, the support resistance is monitored when the long-wall face passing through the abandoned roadway.

\section{Engineering background}

Wulanmulun coal mine is located in the east of Ordos Plateau, inner Mongolia province, China. Because of the production needs, a 12404-1 long-wall face must be set between the 12404-1 tailgate and the 12404-1 headgate, on the west panel of the 12\# coal seam. The average thickness of \#12 coal seam is $2.51 \mathrm{~m}$, the coal seam dip is $1^{\circ}$ to $3^{\circ}$ and the average burial depth of $\# 12$ is $115.24 \mathrm{~m}$. The width of the 12404-1 long-wall face is $113 \mathrm{~m}$, the mining height is $2.8 \mathrm{~m}$, and the advancing length is $542.7 \mathrm{~m}$. As shown in Fig. 1. The new long-wall face must pass through eight abandoned roadways to complete the production. 


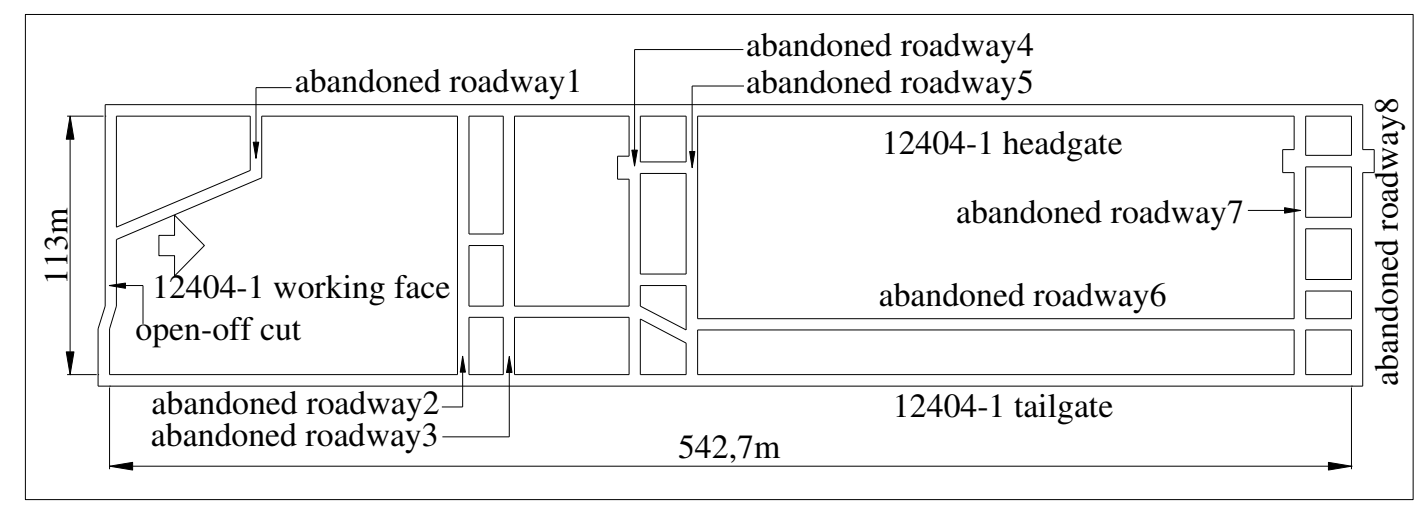

Fig. 1 Plan layout of 12404-1 long-wall face

According to the statistics, all these abandoned rectangular roadways were dug with a width of $5 \mathrm{~m}$, and the height is $3 \mathrm{~m}$. The surrounding rock conditions of the 12404-1long-wall face are specifically shown in Table 1.

Table 1 Surrounding rock conditions of 12404-1 long-wall face

\begin{tabular}{ccc}
\hline Roof $/$ floor & Surrounding rock & Thickness $/ \mathrm{m}$ \\
\hline Main roof & Coarse-grained Sandstone & $8.9-13.3 \mathrm{~m}$ \\
Immediate roof & Fine-grained Sandstone & $0.9-2.7 \mathrm{~m}$ \\
False roof & Argillaceous siltstone & $0-0.6 \mathrm{~m}$ \\
Floor & Mudstone & $2.06 \mathrm{~m}$ \\
\hline
\end{tabular}

\section{Theoretical analysis}

\subsection{Determination of the critical value of coal pillar}

The vertical stress $\left(\sigma_{\mathrm{y}}, \mathrm{MPa}\right)$ of the coal pillar is the overlap of the front abutment pressure and the pressure on one side of the roadway when there were abandoned roadways ahead. the pressure peaks at both sides of the coal pillar will overlap with the advancement of the long-wall face, which means that $\sigma_{\mathrm{y}}$ of the pillar reached the largest. The distribution of abutment pressure is shown in Fig. 2.

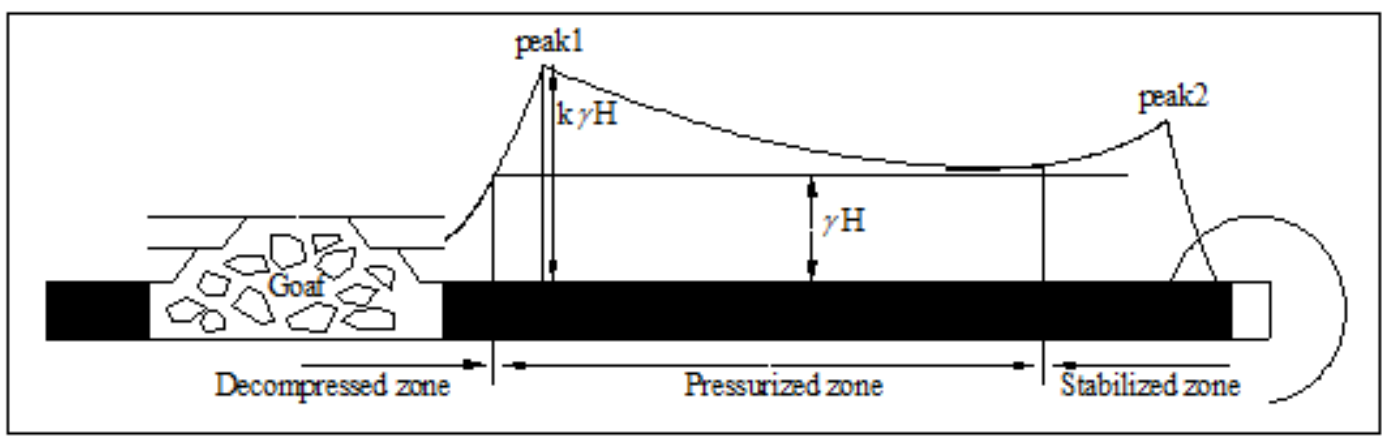

Fig. 2 Abutment pressure distribution 
The distribution of abutment pressure of the long-wall face can be calculated with the following equation [18]:

$$
\sigma_{\mathrm{y} 1}=e^{\frac{2 f x}{M}\left(\frac{1+\sin \varphi}{1-\sin \varphi}\right)}
$$

where $\sigma_{y 1}$ is the vertical stress from the long-wall face side, MPa; $f$ is the interlayer friction factor; $M$ is the mining height, $\mathrm{m} ; x$ is the distance from a certain point in front of the long-wall face to the long-wall face, $\mathrm{m} ; \boldsymbol{\varphi}$ is the internal friction angle, ${ }^{\circ}$.

Simplifying the roadway as circular, the tangential stress is the vertical stress around the roadway, that is [19]:

$$
\sigma_{\mathrm{y} 2}=\frac{r h}{2}(1+\lambda)\left(1+\frac{r_{1}^{2}}{r^{2}}\right)+\frac{\gamma h}{2}(1-\lambda)\left(1+3 \frac{r_{1}^{4}}{r^{4}}\right)
$$

where $\sigma_{y 2}$ is the vertical stress from the roadway side, MPa; $\gamma$ is the bulk density, $N / \mathrm{m}^{3} ; h$ is the burial depth of the roadway, $\mathrm{m} ; \lambda$ is the lateral pressure coefficient; $r_{1}$ is the equivalent radius of roadway, $\mathrm{m} ; r$ is the distance from a certain point around the roadway to the center of the simplified circle, $\mathrm{m}$.

$\sigma_{y}$ of the coal pillar is the sum of $\sigma_{y 1}$ and $\sigma_{y 2}$, when peak1 comes to peak2 with the shrinkage of the coal pillar, the width of the coal pillar reaches the critical value and it will quickly break and go unstable, the coal pillar is only subject to vertical force, $\sigma_{\mathrm{y}}$ at the central position of the coal pillar just reaches the uniaxial compressive strength $\left(\sigma_{c}, \mathrm{MPa}\right)$, which can be calculated with the following equation:

$$
\sigma_{\mathrm{y}}=e^{\frac{f L}{M}\left(\frac{1+\sin \varphi}{1-\sin \varphi}\right)}+\frac{\gamma h}{2}(1+\lambda)\left(1+\frac{4 r_{1}^{2}}{L^{2}}\right)+\frac{\gamma h}{2}(1-\lambda)\left(1+48 \frac{r_{1}^{4}}{L^{4}}\right)
$$

where $L$ is the critical value of the coal pillar width, $\mathrm{m}$.

Base on the Mohr-Coulomb curve, $\sigma_{c}$ can be calculated with the following equation under unidirectional force:

$$
\sigma_{\mathrm{y}}=\sigma_{\mathrm{c}}=\frac{2 c \cos \varphi}{1-\sin \varphi}
$$

According to equation (4), $\sigma_{\mathrm{y}}$ is about 8.3 MPa. Therefore, it can be solved that the critical failure width of the pillar is about $5 \mathrm{~m}$.

\subsection{Mechanism of the roof advanced breaking}

The "Key Strata" theory proposed by Academician Qian [20] believes that the behavior of 
overburden of the coal seam complies whit the key strata(KS), which can be a single strata or a thick stratum. After the coal is mined and the immediate roof collapses instantly, The KS begins to sink and break, forming a series of key blocks (KBs).

Generally, when the roof reached the fracture length, it will break and rotate, which is a periodic and stable process. However, if there is an abandoned roadway ahead, the roof breaking mechanism will change drastically. When the long-wall face passes through the abandoned roadway, the width of the coal pillar is gradually narrowed, and the span of the unsupported roof is increasing, the coal pillar is changed from the original three-way compression to one-way compression and finally destroyed. When the width of the coal pillar reached the critical value, the roof will suddenly lose the coal pillar's support because of the pillar destruction, and abruptly reach or exceed its periodic fracture length, leading to the advanced breaking in which ground pressure appears more intense than the conventional one. The difference between the two is shown in Fig. 3 and Fig. 4.

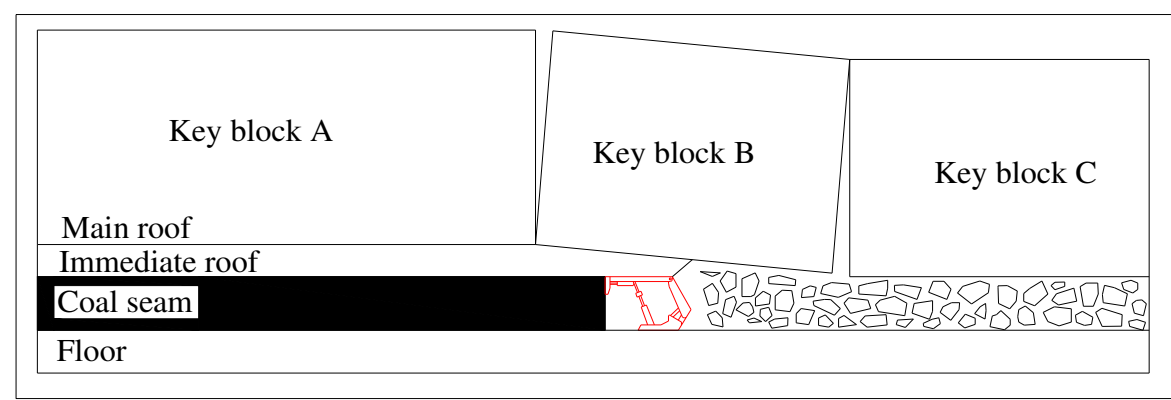

Fig. 3 Roof breaks without abandoned roadway

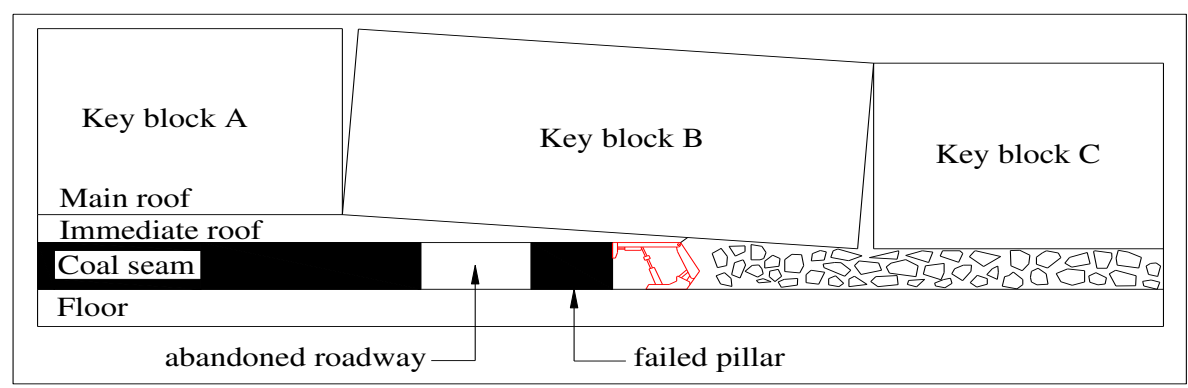

Fig. 4 Roof breaks in advance

\subsection{Stability analysis of KBs}

In order to prevent a series of problems that restrict production and threaten safety, such as coal rib spalling, support crushing, roadway roof falling caused by the advanced breaking of the roof. From the maintenance of the stability of the KBs perspective, the behavioral law of the overlying strata is analyzed, which could provide a theoretical basis for the roof support.

The hinged rock block hypothesis proposed by a scholar of the former Soviet union Г.Н.кузнецов was referred to explain the mechanism [21]. Taking the key block B in Figure 4 as the analysis object, the mechanical balance model where KBs are hinged is established as shown in Fig. 5. 


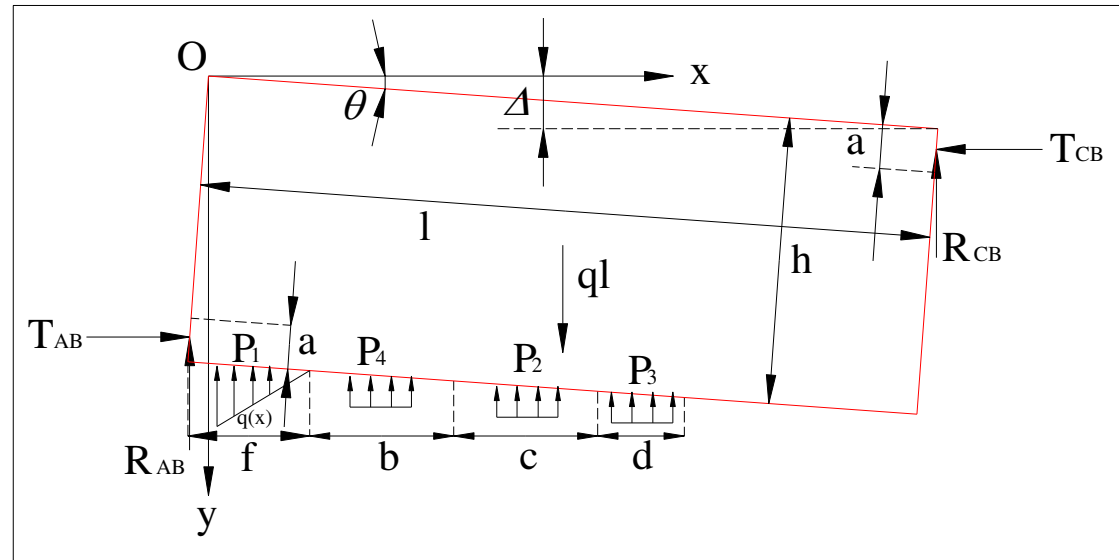

Fig. 5 Mechanical model of key block B

Where $l$ is the advanced breaking length of the main roof, $\mathrm{m} ; a$ is the contact height between block $\mathrm{A}$ and $\mathrm{C}$ and key block $\mathrm{B}, \mathrm{m} ; b, c, d$ and $f$ respectively are the width of the abandoned roadway, the failed coal pillar, the supported roof distance and the length of the key block B above the long-wall face, $\mathrm{m} ; \Delta$ is the rotational subsidence of key block $\mathrm{B}, \mathrm{m} ; q l$ is the sum of the load of the overlying strata and key block B, 2.47MPa; $T_{A B}, R_{A B}$ and $T_{C B}, R_{C B}$ respectively are the horizontal force and shear force which key block $\mathrm{A}$ and $\mathrm{C}$ applied to key block $\mathrm{B}, \mathrm{N} ; \theta$ is the rotation angle of key block $\mathrm{B},{ }^{\circ} ; h$ is the thickness of the main roof, $\mathrm{m} ; P_{1}, P_{2}, P_{3}$ and $P_{4}$ respectively are the supporting force applied by the coal body, residual strength of the failed pillar, hydraulic supporting force, and supporting force on the roof of the abandoned roadway, $\mathrm{KN}$.

Based on the "S-R" stability theory of masonry beam structure, the key block mainly has two modes of sliding instability and rotation instability [22]. To facilitate the analysis of the stability of the key block, we must make the following assumptions:

1) suppose $P_{2}$ acts on $c / 2, P_{3}$ acts on $d / 2, R_{A B}=R_{C B}$;

2) Key block B breaks at the limit equilibrium in the coal body.

Referring to the balance equation on the force and torque, equations following are set:

$$
\sum M_{o}=0 \text { : }
$$

$$
\begin{aligned}
& T_{A B}\left(h-\frac{a}{2} \cos \theta\right)-T_{C B}\left(\Delta+\frac{a}{2} \cos \theta\right)-R_{A B}\left(h-\frac{a}{2}\right) \sin \theta+R_{C B}\left(l \cos \theta-\frac{a}{2} \sin \theta\right) \\
& \quad-\int_{-h \sin \theta}^{0} x q(x) d x+\int_{0}^{f-h \sin \theta} x q(x) d x+P_{2}\left(\frac{c}{2}+b+f-h \sin \theta\right) \\
& +P_{3}\left(\frac{d}{2}+c+b+f-h \sin \theta\right)+P_{4}\left(\frac{b}{2}+f-h \sin \theta\right)-\frac{1}{2} q l^{2} \cos \theta=0 \\
& \sum F_{x}=0: T_{A B}-T_{C B}=0 \\
& \sum F_{\mathrm{y}}=0: R_{A B}+P_{1}+P_{2}+P_{3}+P_{4}+R_{C B}-q l=0
\end{aligned}
$$

Approximates that the length of key block B is the sum of the abandoned roadway's width, the failed pillar's width and the length of the general key block [23], which is: 


$$
l=b+c+l, \quad l^{\prime}=h \sqrt{\frac{R_{T}}{3 q}}
$$

Where $R_{T}$ is the tensile strength of the main roof, MPa.

Define $x_{l}=f+b+c$, which can be calculated by the following equation [24], then $f$ can be solved:

$$
x_{1}=\frac{M \beta}{2 \tan \varphi_{0}} \ln \left[\frac{\beta\left(\sigma_{y} \cos \alpha \tan \varphi_{0}+2 c_{0}-M \gamma_{0} \sin \alpha\right)}{\beta\left(2 c_{0}-M \gamma_{0} \sin \alpha\right)+2 P \tan \varphi_{0}}\right]
$$

Where $M$ is the height of the coal seam, $\mathrm{m} ; \beta$ is the lateral pressure coefficient; $\alpha$ is the inclination of the coal seam, ${ }^{\circ} ; c_{0}$ is the cohesive force on the interface between the coal seam and the roof/floor, $\mathrm{MPa} ; \varphi_{0}$ is the friction angle on the interface between the coal seam and the roof/floor, ${ }^{\circ} ; \gamma_{0}$ is the bulk density of the coal seam, MPa; $P$ is the front-axle beam resistance of the hydraulic support force for the long-wall, MPa.

The support force applied by the long-wall $P_{1}$ can be calculated by the following equation using the limit equilibrium theory [25]:

$$
P_{1}=113 \int_{-\mathrm{h} \sin \theta}^{\mathrm{f}-h \sin \theta}\left(\frac{c_{0}}{\tan \varphi_{0}}+\frac{P}{\beta}\right) e^{\frac{2 \tan \varphi_{0}}{m A} x}-\frac{c_{0}}{\tan \varphi_{0}} d x
$$

From the following equation (11), it is obvious that $\Delta$ is related to the thickness of the immediate roof $H(\mathrm{~m})$, the mining height $M(\mathrm{~m})$ and the loosening coefficient $K_{P}$ of the broken rock seam. And the calculation of $a$ can be given in the geometric relationship after the key block rotation:

$$
\Delta=M-H\left(K_{P}-1\right), a=\frac{1}{2}(h \cos \theta-\Delta)
$$

To ensure that the key block B does not occur slipping instability and rotational instability, Shear force $R_{A B}$ and $R_{C B}$ need to meet inequality(13). Stress at the key block hinged joint $\sigma$ and the compressive strength of the rock block $\sigma_{c}$ needs to meet inequality(12).

$$
\begin{gathered}
\sigma=\frac{T_{A B}}{a} \leq \sigma_{c} \\
R_{A B}=R_{C B} \leq T \tan \varphi
\end{gathered}
$$

Now there are three unknowns $(T, R, P 4)$, but two effective equations (equation 5 and 7 ), base on the previous support experiences and the dichotomy mathematic method, we could try to validly give $P_{4}$, when $P_{4}$ was given to $4020 \mathrm{KN}$ per meter, the $T_{A B}, R_{A B}$ just satisfy both the inequality (12) and (13), which means key block B does not occur slipping instability and rotational instability. 


\section{Numerical Simulation}

To further grasp the stress distribution and deformation law of the rock mass around the stope and the roadway during the 12404-1 long-wall face passing through the abandoned roadway, the FLAC3D numerical simulation software is used to assist this study, which could provide a basis for the support design of the roadway.

\subsection{Model establishment}

According to the geological conditions of 12404-1 long-wall face, a numerical model which is divided into 116160 grids and 124821 nodes is established, as shown in Fig. 6. The size of the numerical model is $200 \mathrm{~m} \times 165 \mathrm{~m} \times 41 \mathrm{~m}$. The numerical model adopts displacement boundary conditions on its surfaces (X, Y direction) and bottom surface ( $\mathrm{Z}$ direction) to fix the horizontal direction (X, Y direction) and vertical direction ( $\mathrm{Z}$ direction) displacement of the node at the boundary. And the upper surface of the model is the stress boundary condition. The value of stress equals to the gravity of the overlying strata, which is $2.5 \mathrm{MPa}$, downward. The model adopts the Mohr-Coulomb failure criterion. The physico-mechanical parameters of coal and strata layers are shown in Table 2.

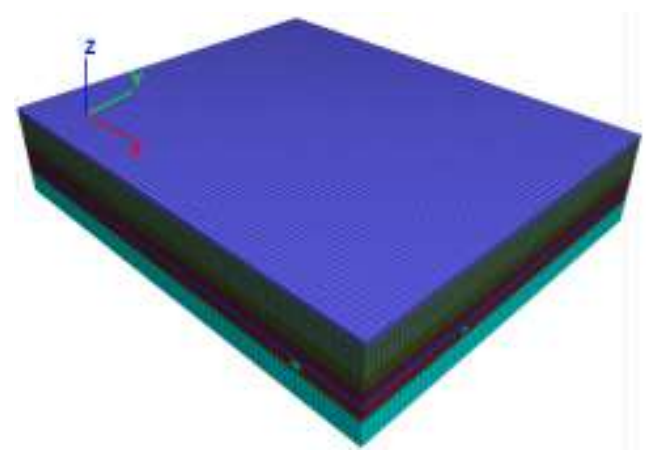

Fig. 6 Numerical model

Table 2 Physical and mechanical parameters of coal and rock layers

\begin{tabular}{lccllll}
\hline Lithology & $\begin{array}{c}\text { density } \\
(\mathrm{kg} / \mathrm{m} 3)\end{array}$ & $\begin{array}{c}\text { Elasticity } \\
\text { modulus } \\
(\mathrm{GPa})\end{array}$ & $\begin{array}{l}\text { Poisson } \\
\text { ratio }\end{array}$ & $\begin{array}{l}\text { Cohesive } \\
\text { force } \\
(\mathrm{MPa})\end{array}$ & $\begin{array}{l}\text { Internal } \\
\text { friction } \\
\text { angle } \\
\left({ }^{\circ}\right)\end{array}$ & $\begin{array}{l}\text { Extension } \\
\text { Strength } \\
(\mathrm{MPa})\end{array}$ \\
\hline $\begin{array}{l}\text { Aeolian } \\
\text { sand }\end{array}$ & 1850 & 3.0 & 0.27 & 1.35 & 12 & 0.5 \\
$\# 12$ coal & 1350 & 8.3 & 0.32 & 2.7 & 24 & 1.2 \\
$\begin{array}{l}\text { Cobble } \\
\text { Mudstone }\end{array}$ & 2510 & 10.85 & 0.147 & 0.01 & 15 & 0.22 \\
$\begin{array}{l}\text { Argillaceous } \\
\text { siltstone }\end{array}$ & 2431 & 8.9 & 0.26 & 1.25 & 29 & 0.605 \\
$\begin{array}{l}\text { Fine- } \\
\text { grained }\end{array}$ & 2560 & 33.4 & 0.235 & 3.25 & 37 & 1.9 \\
$\begin{array}{l}\text { Sandstone } \\
\text { Medium }\end{array}$ & 2457 & 13.5 & 0.123 & 2.16 & 38 & 1.13
\end{tabular}


sandstone

\begin{tabular}{|c|c|c|c|c|c|c|}
\hline $\begin{array}{l}\text { Coarse- } \\
\text { grained } \\
\text { Sandston }\end{array}$ & 2710 & 30 & 0.22 & 2.73 & 36 & 1.6 \\
\hline Loess & 2210 & 2.48 & 1.63 & 1.5 & 36 & 0.6 \\
\hline
\end{tabular}

\subsection{Vertical stress and plastic zone distribution of coal pillar}

With the advancement of the long-wall face, the abutment pressure gradually moves forward, and the width of the coal pillar between the long-wall face and the abandoned roadway is continuously reduced. In Fig. 7(a), when the long-wall face is $7.5 \mathrm{~m}$ away from the roadway, the left side of the roadway begins to appear obvious stress concentration, reaching 6.7 MPa. In Fig. 7 (b) and (c), when the width of the coal pillar goes $5 \mathrm{~m}$, the vertical stress of the pillar begins to decrease, indicating that the coal pillar begins to break and loses its bearing capacity when the width reached $5 \mathrm{~m}$. Continually, when the long-wall face is $2.5 \mathrm{~m}$ away from the roadway, the vertical stress on the left side of the roadway will drop to $6 \mathrm{MPa}-7 \mathrm{MPa}$. The vertical stress of the long-wall face increased rapidly.

With the continuous increase of the vertical stress of the coal pillar, the coal body is changed from the elastic to plastic and eventually lost its bearing capacity. Fig. 7(d)(e)(f) shown the distribution of the plastic zone of the rock mass around the roadway when the distance between the long-wall face and the roadway is $10 \mathrm{~m}, 7.5 \mathrm{~m}$ and $5 \mathrm{~m}$ respectively.

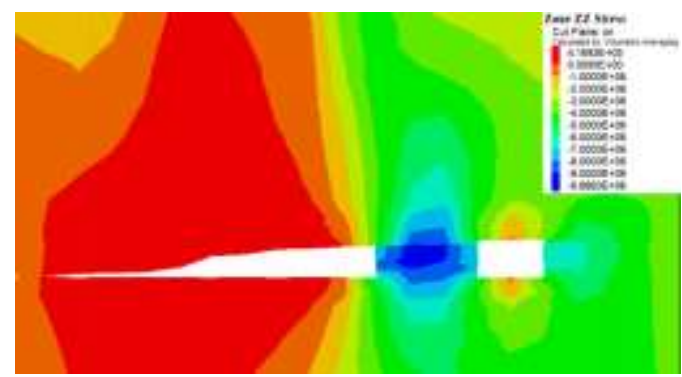

(a) $7.5 \mathrm{~m}$

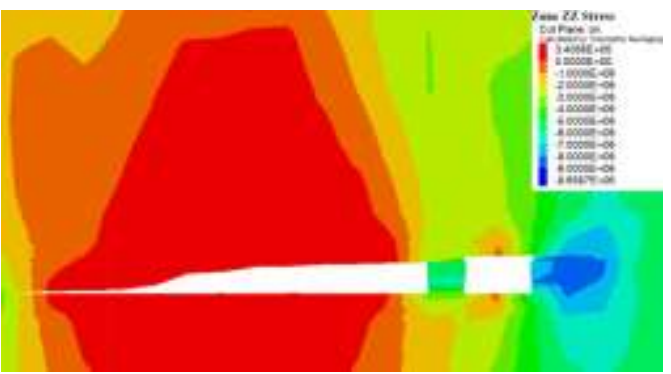

(c) $2.5 \mathrm{~m}$

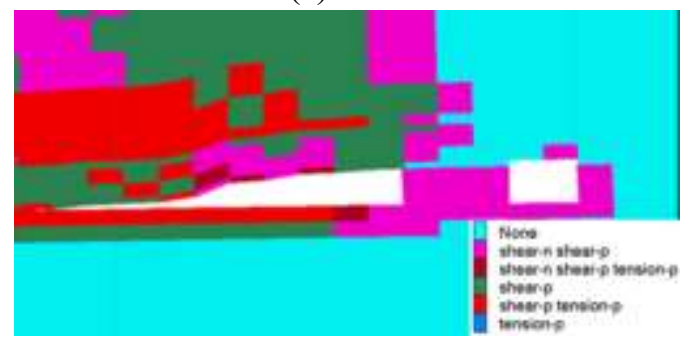

(e) $7.5 \mathrm{~m}$

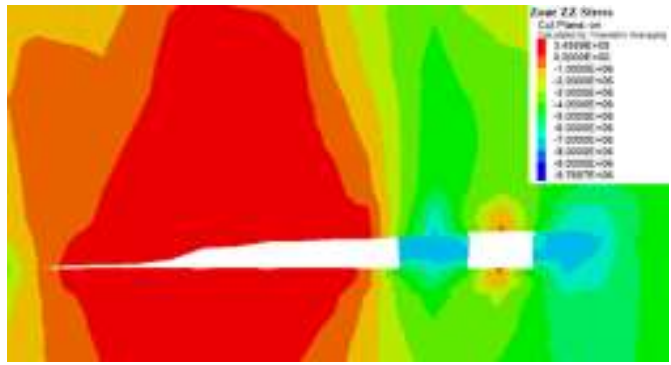

(b) $5 \mathrm{~m}$

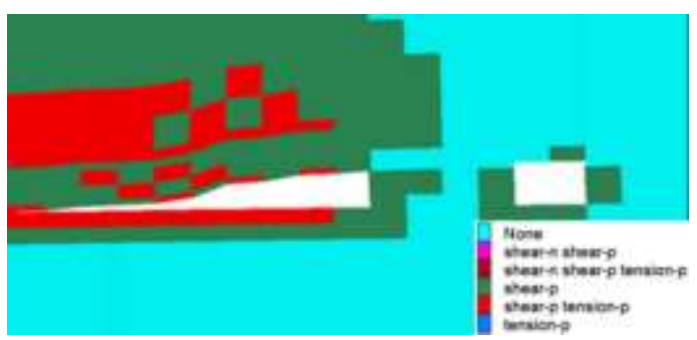

(d) $10 \mathrm{~m}$

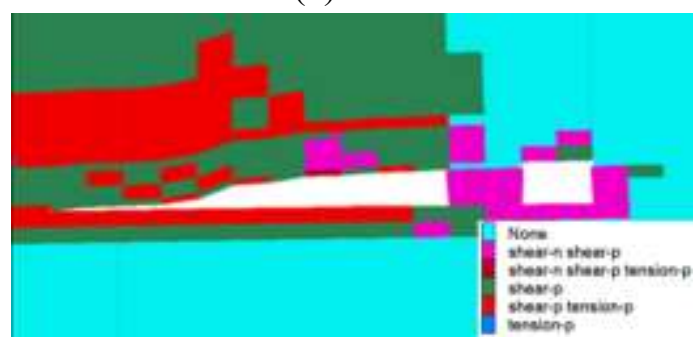

(f) $5 \mathrm{~m}$ 
Fig. 7 Distribution of the vertical stress and plastic zone with different coal pillar widths

\section{Roof controlling technology}

\section{1 roof supporting technology of abandoned roadway}

In order to ensure the safe production of the long-wall face during passing through the abandoned roadway, the roof presplit technique is used to cope with the advanced breaking, reducing the ground pressure at the long-wall face. under the initial support of the abandoned roadway and the theoretical calculation results, a compound support technology - the $22.4 \times 8000 \mathrm{~mm}$ anchor cable supporting and pumping pillar supporting - are added to control the roof of the roadway. As shown in Table 3 and Fig. 8. In Fig.8, the left one is the situation before long-wall face passing through the abandoned roadway, and the right one is after. The unobvious failure of the pumping pillar indicates that this kind of new support design well achieved the engineering purpose.

Table 3 Supporting parameters of roadway roof

\begin{tabular}{|c|c|c|c|}
\hline roadway & $\begin{array}{l}\text { Cross-sect } \\
\text { diagram }\end{array}$ & $\begin{array}{l}\text { Supporting } \\
\text { material }\end{array}$ & specification \\
\hline \multirow{5}{*}{\multicolumn{2}{|c|}{$\begin{array}{l}\text { Abandoned } \\
\text { roadway } 1,2,3,4,5 \mathrm{~m} \times 3 \mathrm{~m} \\
5,7 \text { and } 8\end{array}$}} & $\begin{array}{l}\text { Anchor } \\
\text { cable }\end{array}$ & $\Phi 22.4 \times 8000 \mathrm{~mm}$ \\
\hline & & Tray & $300 \times 300 \times 12 \mathrm{~mm}$ \\
\hline & & \multicolumn{2}{|c|}{ W steel belt $4600 \times 230 \times 2.2 \mathrm{~mm}$} \\
\hline & & Top net & Wire net $45 \times 45 \mathrm{~mm} \backslash 8 \#$ galvanized steel wire \\
\hline & & $\begin{array}{l}\text { Pumping } \\
\text { pillar }\end{array}$ & $\Phi 700 \mathrm{~mm}$ \\
\hline
\end{tabular}
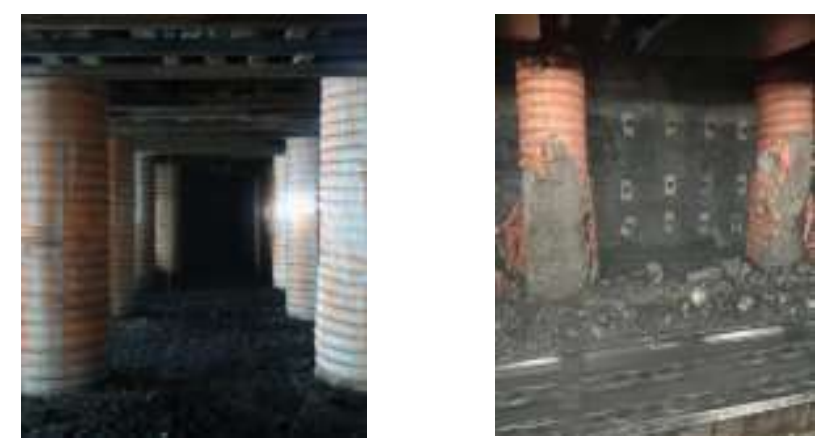

Fig. 8 pumping pillar field model

\section{2 measurement of supporting effectiveness}

The 12404-1 long-wall face adopted the Uroica ground pressure observation system for the monitoring. Fig. 9 shows the support resistance curve of 34\#, 36\# and 38\# supports when the longwall face passing through abandoned roadway 2 and 3. When the long-wall face advances $154 \mathrm{~m}$ and passes through abandoned roadway 2, the roof breaks in advance, compared with no passing through abandoned roadway 2 , the resistance of the support does not increase significantly. When the long-wall face advances $177 \mathrm{~m}$ and begins to pass through the abandoned roadway 3 , the roof 
on the middle of the long-wall face breaks in advance again, except the 34\# support which was set at the middle of the long-wall face, the highest of its resistance reached $470 \mathrm{bar}$, others were basically constant in the process. It shows that the pumping pillar has a better support effect on the roof of the abandoned roadway, it did not cause roof instability.

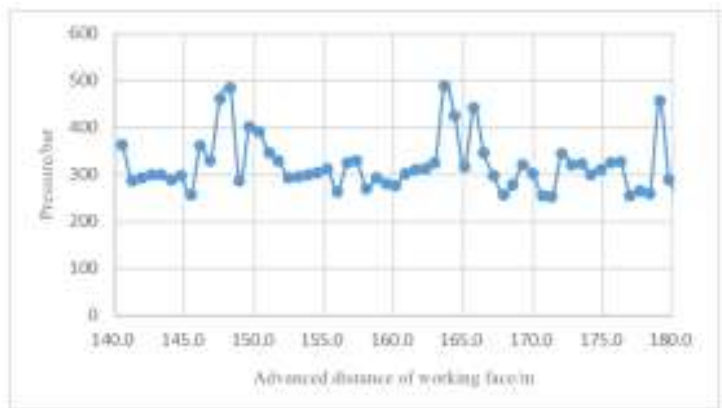

(a) 34 \#support

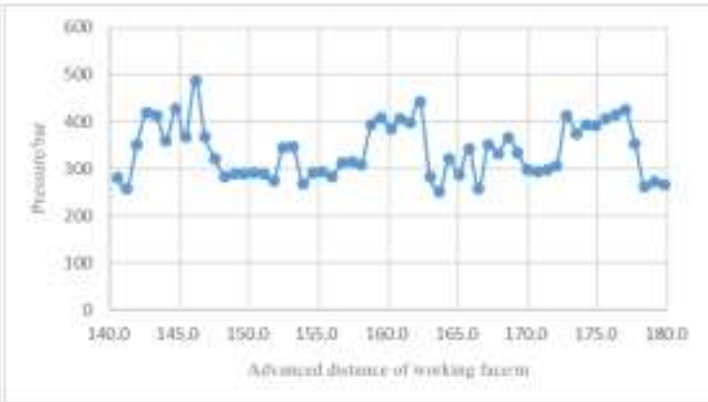

(b) 36\#support

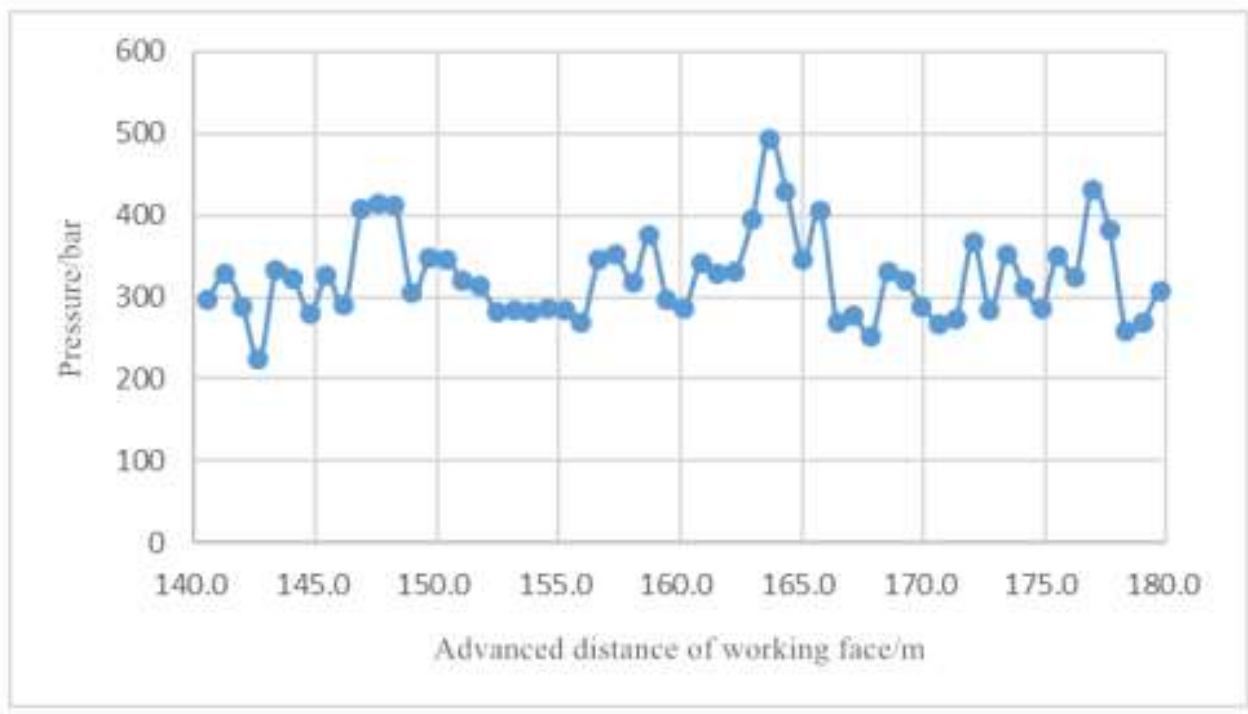

(c) 38 \#support

Fig. 9 Pressure monitoring of supports

\section{Conclusion}

(1) This paper analyzed the distribution characteristics of the vertical stress of the pillar, determined the critical width of the pillar is about $5 \mathrm{~m}$. The mechanism of the roof advanced breaking is revealed and a more refined theoretical model is established to analyze the stability of the key block when long-wall face passing through the abandoned roadway. Accordingly determined the support force for the roof of the abandoned roadway for $4020 \mathrm{KN}$ per meter.

(2) This paper adopted the mathematical method of controlling variables and dichotomy: that is, in the case of three unknowns $(T, R, P 4)$ and two equations. Firstly, validly assume the support force $P 4$ according to the previous experience. Secondly, solve the horizontal force $T$ and the shear force $R$ for key block $\mathrm{B}$, checking the effectiveness of $T$ and $R$. Finally, verify whether $\mathrm{T}$ and $\mathrm{R}$ satisfy the sliding instability and rotation instability conditions, determining the support force of the 
roadway roof to maintain the stability of key block B.

(3) According to the geological conditions of Wulanmulun coal Mine, a model was established to simulate the vertical stress of the coal pillar and the plastic zone distribution of the surrounding rock when the long-wall face passing through the roadway. It is concluded that when the width of the coal pillar is about 5 meters, the bearing capacity of the pillar will drop dramatically, which is in good agreement with the theoretical analysis.

(4) According to the results of theoretical analysis and numerical simulation, a compound surrounding rock control technology is proposed during the long-wall face passing through the roadway, that is, pumping pillar supporting and anchor cable supporting. The monitoring analysis of ground pressure and support effectiveness have achieved the expectation.

\section{References}

[1]Desrues, J, Argilaga, A, Caillerie, D, et al. From discrete to continuum modelling of boundary value problems in geomechanics: An integrated FEM - DEM approach. Int J Numer Anal Methods Geomech. 2019; 43: 919 - 955.

[2]Xu ZH, Zhao YS, Gao HB, et al. Several problems of the old mining remnants in longwall fully mechanized mining technology. J Chin Coal Soc. 2015; 40(S1): 33-39.

[3]Xu QY, Ning ZX, Zhu RS, et al. Study on instability mechanism and top control of overfilled roof in fully mechanized caving face. J Min Saf Eng. 2019; 36(03): 505-512.

[4]Gu SC, Wang BN, Huang RB, Miao Y. Method for determining the load on and width of coal pillar at the recovery room end of fully-mechanized longwall mining. J Chin Univ Min Technol. 2015; 44(06): 990-995.

[5]Li Y, Zhu EG, Zhang KN, et al. Mining methods and roof caving mechanism in longwall mining through the abandoned gateroads of small mines. J Chin Coal Soc. 2017; 42(S1): 16-23.

[6]Sc GU, Huang RB, Li JH, et al. Stability analysis of un-mined coal pillars during the pressure adjustment prior to long-wall face transfixion. J Min Saf Eng. 2017; 34(01): 60-66.

[7]Xie SR, Li SJ, Wei Z, et al. Stability control of support-surrounding rock system during fully mechanized caving face crossing abandoned roadway period. J Chin Coal Soc. 2015; 40(03): 502508.

[8]15Bai JB, Hou CJ. Research on principle of roof stability of abandoned workings and supporting technology. J Chin Coal Soc. 2005; 01: 8-11.

[9]Zhang ZZ, Bai JB, Han ZT, Wang XY, Xu Y, Wang M. Roof mechanics analysis and backfill technology for abandoned roadway. J Min Saf Eng. 2013; 30(02): 194-198.

[10]Zhao T, Liu C. Roof instability characteristics and pre-grouting of the roof caving zone in residual coal mining. J Geophys Eng. 2017; 14(6): 1463-1474.

[11]Liu C, Gong PL, Wang K, et al. Roof stability for repeated mining workface passing through abandoned parallel gateway. J Chin Coal Soc. 2015; 40(02): 314-322.

[12]Liu C, Yang ZQ, Gong PL, et al. Mechanism and control technology of supports crushing induced by main roof's breaking ahead of workface when crossing abandoned roadway. J Chin Coal Soc. 2017; 42(08): 1932-1940.

[13]Wang K, Gong PL, Zhang XQ, Lian Q, Li J, Duan D. Characteristics and control of roof fracture in caving zone for residual coal mining face. Chin J Rock Mech Eng. 2016; 35(10): 2080-2088.

[14]Zhang X, Gong P, Wang K, Li J, Jiang Y. Characteristic and mechanism of roof fracture ahead of the face in an LTCC panel when passing an abandoned roadway: a case study from the Shenghua 
Coal Mine, China. Rock Mech Rock Eng. 2019; 52(8): 2775-2788.

[15]Du, Y, Feng, G, Zhang, Y, Zhang, X, Zhai, Y, Bai, J. Pressure reduction mechanism and effect of long-wall face passing through abandoned roadway by roof presplit. Energy Sci Eng. 2020; 8: 3502-3513.

[16]Wang Q, Gao HK, Yu HC, Liu B. Method for measuring rock mass characteristics and evaluating the grouting-reinforced effect based on digital drilling. Rock Mech Rock Eng. 2019; 52(3): 841-851.

[17]Wang Q, Jiang B, Pan R, et al. Failure mechanism of surrounding rock with high stress and confined concrete support system. Int J Rock Mech Min Sci. 2018; 102: 89-100.

[18] MG Qian, PW Shi, JL Xu, Ground pressure and strata control, China University of Mining and Technology Press, Xuzhou (2010).

[19] Zhilun Xu, Concise course of elasticity[M], 2013.

[20] Xu, J.L., Qian, M.G. Method to distinguish key strata in overburden (2000) Zhongguo Kuangye Daxue Xuebao/Journal of China University of Mining \& Technology, 29 (5), pp. 463-467.

[21]Jinfeng Ju, Jialin Xu, Weibing Zhu, Longwall chock sudden closure incident below coal pillar of adjacent upper mined coal seam under shallow cover in the Shendong coalfield, International Journal of Rock Mechanics and Mining Sciences, Volume 77, 2015, Pages 192-201.

[22] MG Qian, PW Shi, JL Xu, Ground pressure and strata control, China University of Mining and Technology Press, Xuzhou (2010).

[23] Shengrong Xie, Shijun Li, Wei Zhen, Yunjiang Sun, Guangchao Zhang, Baohua Song, Fulian $\mathrm{He}$, Chunyang Tian, Stability control of support-surrounding rock system during fully mechanized caving face crossing abandoned roadway period[J], Journal of China Coal Society, 40(03), 2015, 502-508. (in Chinese)

[24] Yang Ke, Quanming liu, Study on distribution laws of stress in inclined coal pillar for fullymechanized top-coal caving face[J], Chinese Journal of Rock Mechanics and Engineering, 25 (3), 2006, 545-549. (in Chinese)

[25] Chaojiong He, Nianjie Ma, Stress in in-seam roadway sides and limit equilibrium zone[J], Journal of China Coal Society, (4), 1989, 21-29.(in Chinese) 